\section{大腸腺腫発症モデルマウスにおける食餌性 ナガイモおよびナガイモ入り青汁の効果}

木下幹朗 ${ }^{\S}$, 柚木恵太, 得字圭彦, 川原美香*, 大庭＼cjkstart潔*，弘中和憲，大西正男

帯広畜産大学畜産学部畜産科学科

*北海道立十勝圏地域食品加工技術センター

Effect of Dietary Chinese Yam (D. opposita Thunb.) and Leaf Juice (Aojiru) on Aberrant Crypt Foci Formation in 1, 2-Dimethylhydrazine-treated Mice

Mikio Kinoshita ${ }^{\S}$, Keita Yunoki, Yoshihiko Tokuji, Mika Kawahara*, Kiyoshi Ohba*, Kazunori Hironaka and Masao Ohnishi

Department of Agricultural and Life Science, Obihiro University of Agriculture and Veterinary Medicine, Obihiro, Hokkaido 080-8555

* Hokkaido Tokachi Regional Food Processing Technology Center, Obihiro, Hokkaido 080-2462

The dietary effects of Chinese yam, nagaimo (Dioscorea opposita Thunb.), on 1,2-dimethylhydrazine (DMH)-induced aberrant crypt foci (ACF) formation in the large intestine of mice were investigated and compared with those of other potato species. Potato consumption was found to significantly suppress ACF formation in the large intestines of all mice treated with DMH. Suppression of ACF formation was most remarkable in the nagaimo group. Moreover, the commercial product (aojiru) containing nagaimo powder also suppressed ACF formation.

(Received Jun. 30, 2008 ; Accepted Oct. 14, 2008)

Keywords : Chinese yam (nagaimo), aberrant crypt foci, colon cancer, 1,2-dimethylhydrazine, leaf juice (aojiru)

キーワード : ナガイモ, 大腸腺腫, 大腸ガン, 1,2-ジメチルヒドラ ジン, 青汁

前報1) において我々は，食餌性ナガイモ（D. opposita THUNB $)^{2)}$ の 1,2-ジメチルヒドラジン (DMH) による大 腸腺腫 (aberrant crypt foci $(\mathrm{ACF}))$ 発症抑制効果を報告 した。この研究で，ナガイモの加熱処理によっても効果が 維持されることより，ナガイモの機能性食品原料としての 可能性を提示した。しかしながら，この機能はナガイモ独 自の機能かという疑問点は残り，少なくと屯他のイモ類之 の比較が必要である。また，現在の日本人のライフスタイ ルの変化, 特に単身者等の増加を考えると, 今後, 調理済 み食品や簡易な操作で摂取可能な食品を摂取して健康を維

于080-8555 北海道帯広市稲田町西 2 線

* \% 080-2462 北海道帯広市西二十二条北 2 丁目 23-10

\&連絡先 (Corresponding author), kinosita@obihiro.ac.jp
持する方策を見いだすことが重要になる.すなわち，食材と しての機能性はもちろん大事であるが，簡易に摂取出来る 製品を開発し，そのモデルでの機能性の評価屯重要となる.

今回筆者らは $1,2-$ ジメルヒドラジン投与マウスにお ける大腸腺腫 (ACF) 発症に与えるナガイモの効果を，他 のイモ類（ジャガイモおよびサッマイモ）と比較するとと あに，ナガイモ粉末を利用した，商品モデル（ナガイモ入 り青汁）を用いて検討した。

\section{1. 実験方法}

（1） 飼料用ナガイモ等の調製

以下にイモ等の加工方法を記す.

ナガイモ粉：ナガイモ（北海道，平成 18 年産， $100 \mathrm{~kg}$ ) を洗浄した後に表皮を剥離し，すりおろし，レトルト殺菌 機 $\left(100^{\circ} \mathrm{C}\right.$ で 80 分) で加熱 (中心温度 $95 \sim 98^{\circ} \mathrm{C}$ で 25 分), 凍結乾燥および粉砕処理を行って加熱ナガイモ粉を作製し た.

ジャガイモ粉：ジャガイモ（北海道，平成 18 年産品種, ダンシャク，15kg）を洗浄した後に表皮を剥離し，1 cm 程 度に切断，レトルト殺菌機 $\left(100^{\circ} \mathrm{C}\right.$ で 80 分）で加熱（中心 温度 $95 \sim 98^{\circ} \mathrm{C}$ で 25 分), 凍結乾燥および粉砕処理を行っ て加熱ジャガイモ粉を作製した。

サツマイモ粉：サツマイモ（茨城県，平成 18 年産，品種， ベニアズマ，10 kg）を洗浄した後に表皮を剥離し，1 cm 程 度に切断, レトルト殺菌機 $\left(100^{\circ} \mathrm{C}\right.$ で 80 分）で加熱（中心 温度 $95 \sim 98^{\circ} \mathrm{C}$ で 25 分), 凍結乾燥および粉砕処理を行っ て加熱サッマイモ粉を作製した

ダイズ未熟種子（枝豆）：塩無添加のボイル後冷凍市販 品（品種，サヤムスメとサッポロミドリの混合品（北海道， 平成 18 年産)）について凍結乾燥および粉砕処理を行って 粉末枝豆を作製した。

チャ葉粉末 (抹茶)：香岳園製茶(株)（京都府）より購入 した。

小麦葉 (小麦若葉)：小麦若葉 ((有)ランランファーム國 場（北海道）で栽培・収穫, 北海道, 平成 19 年産）を洗 浄・塩素殺菌した後, 温風乾燥, 飽和蒸気殺菌後粉砕し, 小麦若葉粉末を作製した。

（2）in vivo における大腸腺腫の発症抑制試験

i ） 実験動物ならびに試験飼料

動物実験を行うに当たり，帯広畜産大学動物実験指針に 則り, 実験方法等について本学動物実験委員会の承認を受 けた上で動物実験を開始した。

4 週齢の BALB/c 雄マウス（(株)日本クレア）60 匹（1 群当たり 10 匹）ならびにナガイモ入り青汁の組成を予備 検討するため 4 匹，合計 64 匹を用いた11)。また，マウスは 購入後, 市販固形飼料 (F2, (株)船橋農場) で 1 週間飼育 した後，試験飼料に切り替えた。試験飼料は AIN-93G ${ }^{3)}$ の 処方に基づいて調製した。 すなわち, コントロール群 (AIN93G 食), ナガイモ投与群（AIN-93G+ナガイモ粉（25 g) 
$100 \mathrm{~g}$ 飼料)), ジャガイモ群 ((AIN-93G + ジャガイモ粉 (24 g/100 g 飼料))，およびサツマイモ群 (AIN-93G+サツ マイモ粉 $(23 \mathrm{~g} / 100 \mathrm{~g}$ 飼料)) の 4 群に分けた。なお, イモ 粉末の投与量については，5訂食品成分表 ${ }^{4)}$ の各イモ類の 組成を参考にデンプン含量を算出し, AIN-93G のコーンス ターチ部分を調製ナガイモ粉末に置き換え, デンプン（炭 水化物）の量を統一した. すなわち, 各イモ類の場合 AIN93Gのコーンスターチ部分の 50\%を置換したことになる.

商品化モデルとしてのナガイモ入り青汁における評価と して，青汁成分として小麦若葉 $(1.3 \mathrm{~g} / 100 \mathrm{~g}$ 飼料), 枝豆 ( $1.35 \mathrm{~g} / 100 \mathrm{~g}$ 飼料) ならびに抹茶 $(0.5 \mathrm{~g} / 100 \mathrm{~g}$ 飼料) およ びナガイモ ( $1.35 \mathrm{~g} / 100 \mathrm{~g}$ 飼料) を添加した。なおこの組成 は (有)ランランファームより提供された処方に準拠した. 実験群としては青汁成分のみ加えた青汁群ならびにそれに ナガイモを添加したナガイモ入り青汁群で評価した。な お, ナガイモ入り青汁投与群では, ナガイモの添加量がナ ガイモのみを投与する群と比較して著しく低い.これは, ナガイモの量を増加させると青汁関連素材の量が増加し, 嗜好性等の問題よりマウスの摂食量等に影響を及ぼすこと が危惧されたため, 本試験を行う前に摂食量について 4 匹 で試験を予備的に行い（AIN93 食と青汁投与群），摂食量 と体重变化がコントロール群 (AIN-93 食) と差がない摂取 量の飼料組成を青汁ならびにナガイモ入り青汁群として採 用した。 また，食餌，飲水は各群とも自由摂取とした。

ii）大腸腺腫の測定

試験食投与（各種イモ類ならびに青汁群） 1 週間後より 大腸ガン誘発物質である DMH (1, 2-dimethylhydrazine dihydrochloride）を $30 \mathrm{mg} / \mathrm{kg}$ 体重で週 1 回（合計 8 回） 腹腔内投与した。 8 週間試験食で飼育した後, 24 時間絶食 させてからエーテル麻酔下中枢破壊（頸椎脱臼処理）によ り屠殺し, 大腸 (虫垂から肛門部まで) を摘出した ${ }^{5) 6}$. 摘 出した腸管の片側を縫合糸で結搾した後，4\%ホルマリン を注入し，大腸の両端を結搾して大腸が膨潤した状態で 1 昼夜固定した。 その後, 大腸を切り開き, 幅と長さを測定 した. 次いで, $0.3 \%$ メレンブルーで染色し, 顕微鏡下で $\mathrm{ACF}$ 数を計測 ( ${ }^{6)}, \mathrm{ACF}$ 数は大腸表面積当たりで算出し た。なお, 大腸腺腫の発症を確認するため, 投与開始 5 週 間後より, 各群 1 匹ずつ各週上記の方法で解剖検鏡し, 解 剖週（8 週）を決定した。

iii）統計処理

統計処理は, 一元配置分散分析の後, Scheffe の多重比 較検定により行い, 危険率 $1 \%$ 以下を有意差と判定した. また，危険率 $10 \%$ 以下を傾向を有すると判定した。

\section{2. 実験結果および考察}

$\mathrm{DMH}$ 投与期間の体重の变化は，コントロール群を含め て各群における有意な体重の变化は認められなかった。

顕微鏡下で ACF の形態1) を示す組織の数を計数し, 組 織単位面積当たりの ACF の発症率を算出した (Fig. 1).

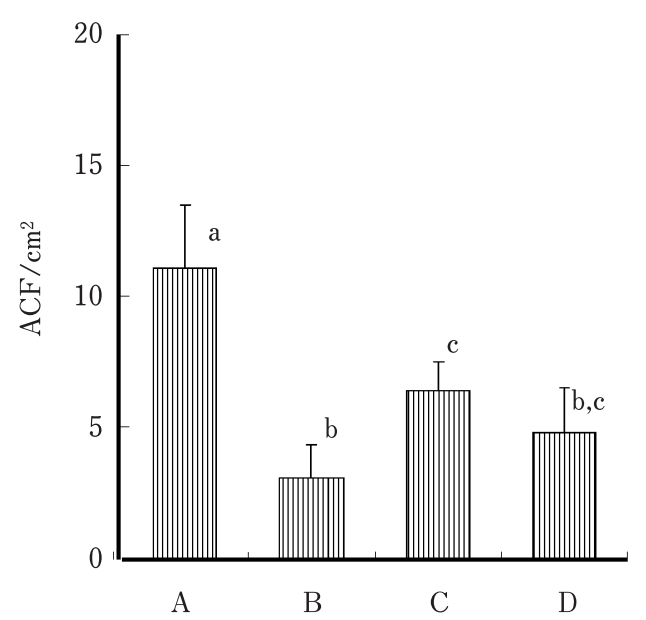

Fig. 1 Effects of dietary Chinese yam on DMH-induced aberrant crypt foci formation in mouse large intestine

A, feeding by AIN-93G; B, AIN-93G with Yam powder (25\% of diet) ; C, AIN-93G with Potato powder $(24 \%$ of diet); D, AIN-93G with Sweet potato powder $(23 \%$ of diet). Values are means $\pm \mathrm{SD}(\mathrm{n}=7)$.

a,b,c Values with different superscript letters in column differ significantly $(P<0.01)$.

その結果, $\mathrm{ACF}$ 数の平均值は, コントロール群で大腸 $1 \mathrm{~cm}^{2}$ 当たり $11.4 \pm 2.4$ 個 (平均値士標準偏差) であった。一方, ジャガイモ粉投与群では $6.1 \pm 1.1$ 個, サッマイモ投与群で は $4.8 \pm 1.7$ 個およびナガイモ投与群では $3.0 \pm 1.3$ 個であっ た。イモ類投与群すべてにおいてコントロール群と比較し て有意に大腸腺腫を抑制する効果が認められた。一方, イ モ類同士で比較してみると，ジャガイモとナガイモの間で は有意にナガイモが大腸腺腫発症を抑制した。 また，サッ マイモ群とナガイモ群では有意な差は認められなかった が, ナガイモ群で抑制される傾向が見られた $(P=0.09)$.

今回の研究では，イモ類間での大腸線腫発症抑制効果を 比較した。 これらイモ類は植物種としては決して近縁では ない(ジャガイモはナス科, サッマイモはヒルガオ科およ びナガイモはヤマノイモ科).しかし我が国拈いて食料と して考える場合，イモ類として同一のカテゴリーに入る. 今回は，イモ類に含まれる構成分を分画して行った実験で はないので，生理活性画分の同定はできない，イモ類の主 成分はデンプンである（乾燥重量当たり概ね 70-85\% ${ }^{4)}$ ). 食物繊維量 $\left.{ }^{4}\right)$ は, サッマイモが最も高く $6.8 \%$ (乾燥重量当 たり）で，ジャガイモおよびナガイモは $1 \%$ である. 貯蔵 蛋白質の生重量当たり概ね 1-2\%であり，含量に際だった 差は認められない. 今回の結果について, デンプンや食物 繊維の違い（レジスタントスターチ7)など）や，貯蔵タンパ ク質 (ナガイモの場合は Dioscorin ${ }^{8)}$ ) の生理作用, または その他微量成分や成分間の相乗作用なのかについて今後, 各物質レベルでの実験が重要になる，また，各イモ類の品 種や栽培方法による異同についても検討する必要があろ 


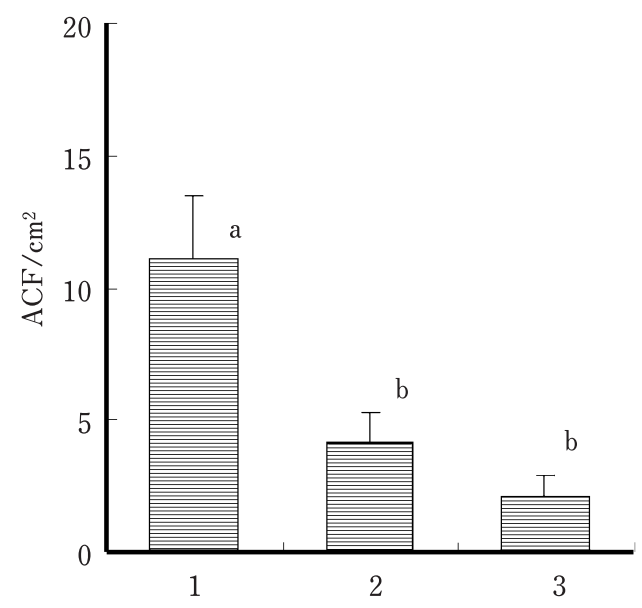

Fig. 2 Effects of commercial product using Chinese yam (Aojiru containing Chinese yam) on DMHinduced aberrant crypt foci formation in mouse large intestine

1, feeding by AIN-93G; 2, AIN-93G with; Aojiru(young wheat leaves, young soybeans and powdered green tea) ; 3, AIN-93G with Aojiru and yam powder; Values are means $\pm S(n=7)$.

${ }^{\mathrm{a}, \mathrm{b}}$ Values with different superscript letters in column differ significantly $(P<0.01)$.

う.

市販モデル（ナガイモ入り青汁）を用いての評価の結果, 青汁部分のみ (小麦若葉と枝豆ならびに抹茶) を混合した 飼料で飼育した青汁群では $4.1 \pm 1.2$ 個，青汁にナガイモ粉 末を加えたナガイモ入り青汁群では $2.1 \pm 0.8$ 個であった (Fig. 2). すなわち, 青汁群ならびにナガイモ入り青汁群に おいてあコントロール群と比較して有意に強く大腸腺腫を 抑制した。これにナガイモを混合したナガイモ入り青汁群 では有意な差は認められなかったが, ナガイモ入り青汁群 で抑制される傾向が見られた $(P=0.09)$.

また，青汁に混合した枝豆 (ダイズ ${ }^{9)}$ ならびに抹茶成 分10111) に扔いても, DMH 投与動物への ACF 発症効果が 報告されていることより，これらの成分とナガイモとの相 乗むしくは相加作用によるものと考えられ，大腸腺腫抑制 の意味でもナガイモ入り青汁は機能性食品として有効であ ると考えられる。

以上の結果より, 食餌性ナガイモの大腸腺腫発症抑制効 果は他のイモ類と比べて高かった。 また，市販モデル（ナ ガイモ入り青汁）の場合でも大腸腺腫発症抑制効果が認め られた。

\section{3. 要 約}

食餌性ナガイモの大腸腺腫発症に与える効果を他のイモ 類と比較しつつ，1，2-ジメチルヒドラジン投与マウスを用 いて調べるとともに，ナガイモを利用した商品モデル（ナ
ガイモ入り青汁）の効果についても検証した。その結果, ナガイモ以外のイモ類においても上記の実験動物モデルに おいて大腸腺腫抑制効果が観察されたが，腺腫数の平均は ナガイモ群が一番低かった。.また, 商品モデルであるナガ イモ入り青汁ついても腺腫抑制効果が観察された。

本研究は文部科学省都市エリア産学官連携促進事業「十 勝エリア」(機能性を重視した十勝農畜産物の高付加価値 化に関する技術開発）の研究課題の一部として行われた.

\section{文献}

1）木下幹朗, 柚木恵太, 得字圭彦, 川原美香, 大庭 潔, 弘中 和憲，大西正男，1,2-ジメチルヒドラジン投与マウスにお ける大腸腺腫発症に与える食餌性ナガイモの効果, 食科工, 55, 270-275 (2008).

2）佐藤一郎，野菜園芸大百科，第 2 版「サトイモ，ナガイモ， レンコン，ウド，フキ，ミョウガ」，(農文協，東京), pp 6378 (2004).

3) Reeves, P. G., Nielsen, F. H. and Fahey, G.C., Jr., AIN-93 purified diets for laboratory rodents : final report of the American Institute of Nutrition ad hoc writing committee on the reformulation of the AIN-76A rodent diet. $J$ Nutr, 123, 1939-1951 (1993).

4）科学技術庁資源調査会編 $「 5$ 訂食品成分表」，(女子栄養大学 編集部，東京）pp. 44-45（2001）.

5) Mclellan, E. and Bird, R.P., Effect of Disulfiram on 1,2dimethylhydrazine-induced and azoxymethane-induced aberrant crypt foci. Carcinogenesis, 12, 969-972 (1991).

6) Aida, K., Kinoshita, M., Tanji, M., Sugawara, T., Tamura, M., Ono, J., Ueno, N. and Ohnishi, M., Prevention of aberrant crypt foci formation by dietary Maize and yeast cerebrosides in 1,2-dimethylhydrazine-treated Mice. J. Oleo Sci., 54, 45-49 (2005).

7) Charalampopoulos, D., Wang, R., Pandiella, S.S. and Webb, C., Application of cereals and cereal components in functional foods : a review. Int J Food Microbiol, 79, 131-141 (2002).

8) Shewry, P.R., Tuber storage proteins. Ann Bot (Lond), 91, 755-769 (2003).

9) Weed, H.G., McGandy, R.B. and Kennedy, A.R., Protection against dimethylhydrazine-induced adenomatous tumors of the mouse colon by the dietary addition of an extract of soybeans containing the Bowman-Birk protease inhibitor. Carcinogenesis, 6, 1239-1241 (1985).

10) Inagake, M., Yamane, T., Kitao, Y., Oya, K., Matsumoto, H., Kikuoka, N., Nakatani, H., Takahashi, T., Nishimura, H. and Iwashima, A., Inhibition of 1,2-dimethylhydrazine-induced oxidative DNA damage by green tea extract in rat. Jpn J Cancer Res, 86, 1106-1111 (1995).

11) Yin, P., Zhao, J., Cheng, S., Zhu, Q.,Liu, Z. and Zhengguo, L., Experimental studies of the inhibitory effects of green tea catechin on mice large intestinal cancers induced by 1,2-dimethylhydrazine. Cancer Lett, 79, 33-38 (1994).

(平成 20 年 6 月 30 日受付，平成 20 年 10 月 14 日受理) 